\section{Asbestos Fibre and Mineral Counts from Filtered Dust Collected in Human Settlements Asbestos Mine Dumps in Mpumalanga Province, Republic of South Africa}

\author{
Kwata MG ${ }^{1,2 *}$, Moja $\mathbf{S J}^{1,2}$, Masindi $\mathrm{K}^{1,2}$, Mtyelwa $\mathbf{O}^{1,2}$ and Malatji \\ $\mathbf{M}^{1,2}$
}

'Water and Environment, Geological Resources Unit, Council for Geoscience, 280 Pretoria Street, Silverton, Pretoria, 0184, South Africa

${ }^{2}$ Department of Environmental Sciences, Florida Campus, University of South Africa, P O Box X6, Florida, 1710, South Africa

\begin{abstract}
Dust generation sources come from mining sites including mine dumps, crushing, hauling, grinding and offloading of waste material from open pit and underground operation and non-operations, movement of trucks on unpaved roads, etc. Many mine dumps in South Africa are not rehabilitated due to the possibility of re-mining in the case of asbestos dumps or have been abandoned by previous owners for different reasons. Some of the reasons for abandonment include bankruptcy, ineffective enforcement, lack of financial assurance, minimal penalties for non-compliance and commodities like gold, asbestos and coal are affected. Historically, only long asbestos fibres were used for manufacturing purpose. While short fibres were unwanted and dumped with other waste material and today heaps of such waste materials are the source of airborne asbestos fibre pollution. Asbestos mining in South Africa was ceased in 2002 mainly due to the associated human health problems. This study aims to measure the level of asbestos fibre concentration in airborne dust samples using Phase Contrast Microscope (PCM). The \% mineral
\end{abstract}

*Corresponding author: Kwata MG, Water and Environmental, Applied Geoscience, Council for Geosciences, 280 Pretoria Road, Silverton Pretoria, 0001, Republic of South Africa, Tel: +27128411387; Fax: +27865132274: Email: mkwata@geoscience.org.za, maphuti.kwata@gmail.com

Citation: Kwata MG, Moja SJ, Masindi K, Mtyelwa O, Malatji M (2019) Asbestos Fibre and Mineral Counts from Filtered Dust Collected in Human Settlements Asbestos Mine Dumps in Mpumalanga Province, Republic of South Africa. J Environ Sci Curr Res: S1003.

Received: May 31, 2019; Accepted: September 05, 2019; Published: September 16,2019

Copyright: () 2019 Kwata MG, et al. This is an open-access article distributed under the terms of the Creative Commons Attribution License, which permits unrestricted use, distribution, and reproduction in any medium, provided the original author and source are credited. count in filtered dust samples were analysed using Scanning Electron Microscope-Energy Dispersive Spectrometry (SEM-EDS) techniques. The AirCon 2 sampler was used to collect airborne asbestos with an air flow rate of $2.0 \mathrm{~L} / \mathrm{Min}$ for 24 hours. Filtered dust fallout samples were collected using single dust bucket unit exposed onsite for a period of 30 days following the local Dust Control Regulations. The results from July to December 2017 shows the following concentrations Site A with $572 \mathrm{f} / \mathrm{mL}$, Site B with $2.189 \mathrm{f} / \mathrm{mL}$ in July 2017, in August 2017 at Site D with $572 \mathrm{f} / \mathrm{mL}$, Sites A\& E with $1.845 \mathrm{f} / \mathrm{mL}$ and from October to December 2017 sample damaged. SEM-EDS results show that amphibole asbestos mineral group detected at all the sites and other silicate mineral detected were quartz, and feldspar.

Organic material was detected. Serpentine asbestos mineral group was not detected at all the sites.

Keywords: Asbestos fibre count; Former asbestos mine dumps; Mineral count; Mpumalanga Province

\section{Introduction}

Asbestos designates a group of naturally occurring fibrous serpentine or amphibole mineral groups that have extraordinary tensile strength, conduct poorly and are relatively resistant to chemical attack [1]. The chemical compositions and physical properties identify positively are sometimes troublesome [2]. Natural sources are important because asbestos minerals are widely spread throughout the earth's crust and are not restricted to the few mineable deposits [3]. Exposure of asbestos fibre are due to natural weathering and can be enhanced by man activities such as mining, milling, manufacture of products, construction activities, transport and use of asbestos-containing products and disposal. In industrial factories most of the asbestos used was in the building sectors [4]. There has been a steep rise in the production and use of asbestos in the past which lead to health problems [5]. Asbestos fibres of respirable size form part of a range of fibrous aerosols in the lower atmosphere [6]. Once emitted into the atmosphere asbestos fibres may travel considerable distances owing to the aerodynamic properties [7]. Asbestos fibres normally constitute only a relatively small fraction of the total fibrous aerosol in ambient air [8,9]. The purpose of the study is to determine asbestos fibre count concentration from mounted filter cassette and determine the morphology from filtered dust samples.

\section{Location of the Study Area}

The province is known to have pine trees and escarpment which most of these trees are owned by SAPPI [10]. The province geology is Komatities, Tjakkastad, Chuenespoort Supergroup and ultramafic and malfic rocks from the Barberton green stone belt [11]. The asbestos mineral occurs in banded iron formation (magnesium and iron rich). The asbestos field was discovered by Dr Anhaeusser, [11] in Kaapsehoop. The geology stretch to Doyreshoek, Stolzburg and Strekspruit which forms part of the Nkomazi Game Reserve between Lokwatini and Badplass [12]. The occurrence of the asbestos fields stretched to on the way to Malelane and Carolina [13] (Figure 1). 


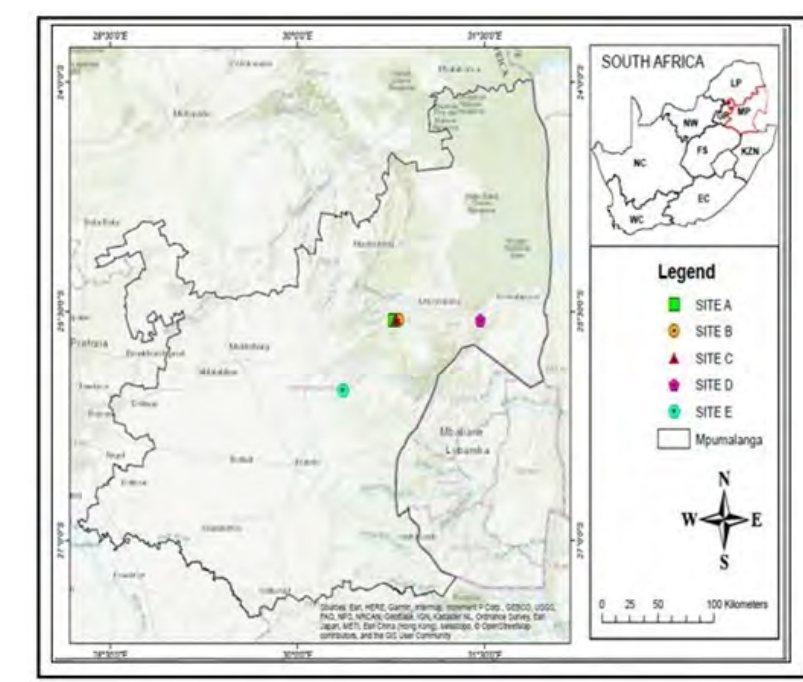

Figure 1: A map shows the location for sampling sites.

\section{Methodology}

\section{Sample collection}

AirCon 2 high volume: This equipment operates with a power source collects particles from the air and later collected samples are analysed in the laboratory. A filter substrate is mounted in cassette for the collection of the sample. It has its own external battery and is deployed on the site for twenty four (24) hours. It operates just like an e-sampler, except that it does not have a light scattering method and it only uses a gravimetric method by collecting the dust suspended in the air. It can be used for shorter campaigns that can stretch for one hour or more. The Aircon-2 high volume air sampler was used to collect dust samples outdoors on all the sites. The unit is set up in human settlements for 24 hours and operated using a power module which is designed to power the unit from a standard AC source. A 2.0 L/Min flow rate was maintained for at 24 hours at each site. The volume of the air that passes through the filter cassette was calculated to $2.0 \mathrm{~L} /$ Min and the sampling cassette (with filter inside) was clearly labeled and stored in an upright position throughout (Figure 2).

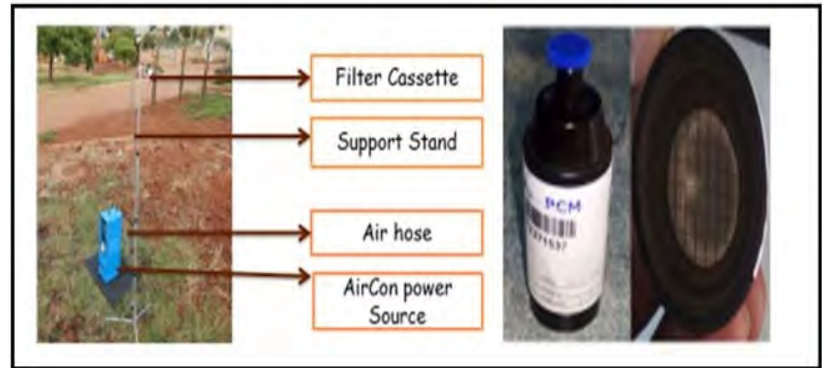

Figure 2: AirCon 2 high volume sampler; filter cassette, filter cassette, support stand, air hose, aircon power sources and the inside of the filter cassette.

Single dust bucket unit: A standard method for collection and analysis of settleable dust adopted from the South African National Dust Control Regulations [14] was used in the research. This method specifies dust particles being measured with aerodynamic diameters of less than $100 \mu \mathrm{m}$. Settleable dust monitoring units are placed within the nearest human settlements. The bucket is hoisted on a $2 \mathrm{~m}$ stand above the ground. A collector/ container must have the following specifications: an open topped cylinder with vertical sides and a flat bottom, minimum $15 \mathrm{~cm}$ diameter with a depth of 2-3 times diameter (Figure 3). It may be made of glass, plastic or stainless steel but glass is not preferable because of it is fragile. The collector should thoroughly rinse the cylinder and use distilled /deionized water in the container so that the level is half of the container's depth when the test is started (Figure 3). In cold weather, a sufficient volume of antifreeze should be added to prevent freezing, while in warm weather, sufficient copper sulfate as an algaecide should be added to give 15 $\mathrm{mg} /$ liter concentration. The stand design is the most debated aspect of the method. According to ASTM D1739 - 1970, the holder should not interfere with the operation of the collector in any way, a bird ring must be provided (Figure 3) and the top of the container should be 2.4 $\mathrm{m}$ minimum above the ground. Normally samples must be collected for every 30 days \pm 2 days. After 30 days, the container which was exposed for 30 days on site is replaced with another one with half distilled/deionized water for another 30 days.

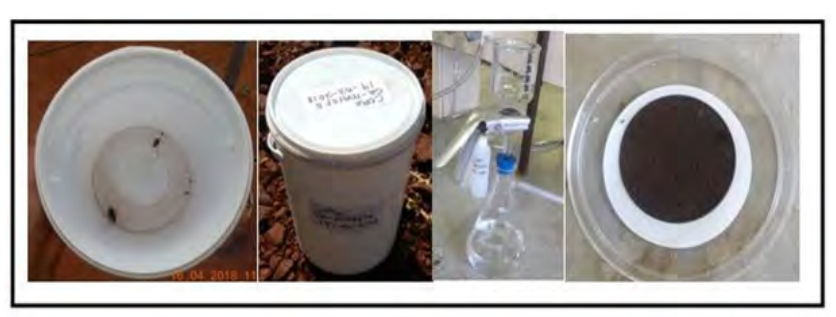

Figure 3: Single dust bucket unit and filtration system.

The settleable dust rate is defined as the rate of the deposition of the dust [15]. Settleable dust sampling measures the fraction of dust greater than $30 \mu \mathrm{m}$ diameter that will settle from the atmosphere under force of gravity. Single bucket settleable dust monitors/units were deployed following the American Standard Testing Methods (ASTM D1739-1970) for collection and analysis of settleable dust.

\section{Laboratory analysis}

SEM-EDS analysis: Scanning electron microscopy-energy dispersive spectroscopy determines morphology which includes the size, shape, length, width and types of asbestos groups detected on the filtered dust samples. The filtered dust samples are mounted on specialized filter holders for SEM-EDS investigations. For SEM analysis, powders are prepared as grain mounts. All specimens for SEM-EDS are coated with carbon to provide a conductive surface for optimum imaging and X-ray microanalysis. The laboratory analysis assists with the understanding of the general behaviour of settleable dust and characterization of airborne dust contaminated with asbestos dust [16].

Physical phase contrast microscope asbestos fibre counting: The procedure for filter analysis using the phase contrast microscope the filter is cut in quarter from the original filter. Then, clean tray or slide is divided into 200 fields for the asbestos fibre counting. The phase contrast microscope is adjusted to high magnification from $22 \mathrm{~mm}$ to 300 $\mathrm{mm}$ and the graticule is used to determine whether the counted fibre in is length $>5.0 \mu \mathrm{m}$ and $<3.0 \mu \mathrm{m}$ diameter with aspect ratio of $3: 1$. 
The asbestos fibre counting begins in the laboratory where the filter substrates are divided into 200 fields on the tray slide for physical fibre count under microscope.

\section{Quality control}

AirCon 2 high volume sampler: AirCon 2-High Volume sampler (Model number F-PRO-3100) must be set up in the vertical position to maintain the rotameter in the correct position and optimised accuracy. The rotameter provided in this sampler has been tested for accuracy and is within $\pm 5 \%$ of full scale. The bottom legs of the sampler opened by unfolding the lock knot and pulling the legs outwards as far as they could extend.

The largest locking collar at the bottom of the stand was loosened and pulled out; the second largest locking collar was also pulled out and the largest collar tightened. Holding the extended section, the second largest locking collar was loosened and extended along the next section of the mast. The second largest collar was tightened and this procedure was repeated until the mast was extended to its full or required height. Care was taken to tighten each locking collar before proceeding to loosen the next. The extended mast was positioned next to the sampler. The sampler operation flow ranged from 2 to 3 LPM and constant flow capabilities ranged from 2 to 3 LPM @ pressure up to $7 \mathrm{psi}$, operating temperature range from $-20^{\circ}$ to $45^{\circ} \mathrm{C}\left(-4^{\circ} \mathrm{F}\right.$ to $\left.113^{\circ} \mathrm{F}\right)$, storage temperature range from $-40^{\circ}$ to $45^{\circ} \mathrm{C}\left(-40^{\circ}\right.$ Pascal to 113 Pascal), humidity from 0 to $95 \% \mathrm{RH}$ (Relative humidity). The sampler was calibrated by the supplier once a year [17].

Single dust bucket unit: Settleable dust rates (mass concentration) analysis for the quality control is required. First, the weigh mass must be calibrated before use and evaporation dishes should be checked to ensure they are clean. The laboratory's cleanliness should be checked to ensure no dust on the laboratory desks before the filtration process starts. The personal protection clothes must be worn during laboratory working hours from beginning to end. Gloves, boots, goggles, asbestos dust masks and laboratory coat must be worn at all times. The following apparatus must be cleaned: beaker, connector, buchner funnel, pipe and the vacuum pipe.

\section{Result}

The SEM-EDS results shows that all the sites detected amphibole asbestos mineral, whichc ould are the results of formation under different conditions. In this province, chrysotile was the asbestos mineral mined and it could be that while chrysotile was mined accidentally amphibole asbestos mineral was exposed. Another reason is that it could be resulted from wind blowing because fibrous materials suspended in the air and transportation from one province to another. Other silicate minerals detected were quartz, kaolinite and feldspar. Organic material was detected (Figures 4,5).

From the chemical formula of silicate minerals and theses common elements were detected and scanned during the analysis for SEM-EDS including Carbon (C), Iron (Fe), Magnesium (Mg), Lead $(\mathrm{Pb})$, Potassium $(\mathrm{K})$, Calcium $(\mathrm{Ca})$ and Sulphate $(\mathrm{S})$.

All airborne asbestos fibres which were captured on the filter substrates per 200 fields with length $>5.0 \mu \mathrm{m}$ and $<3.0 \mu \mathrm{m}$ diameter were above the limit value of $100 \mathrm{f} / \mathrm{mL}$ [2] for asbestos fibre suspension in air.
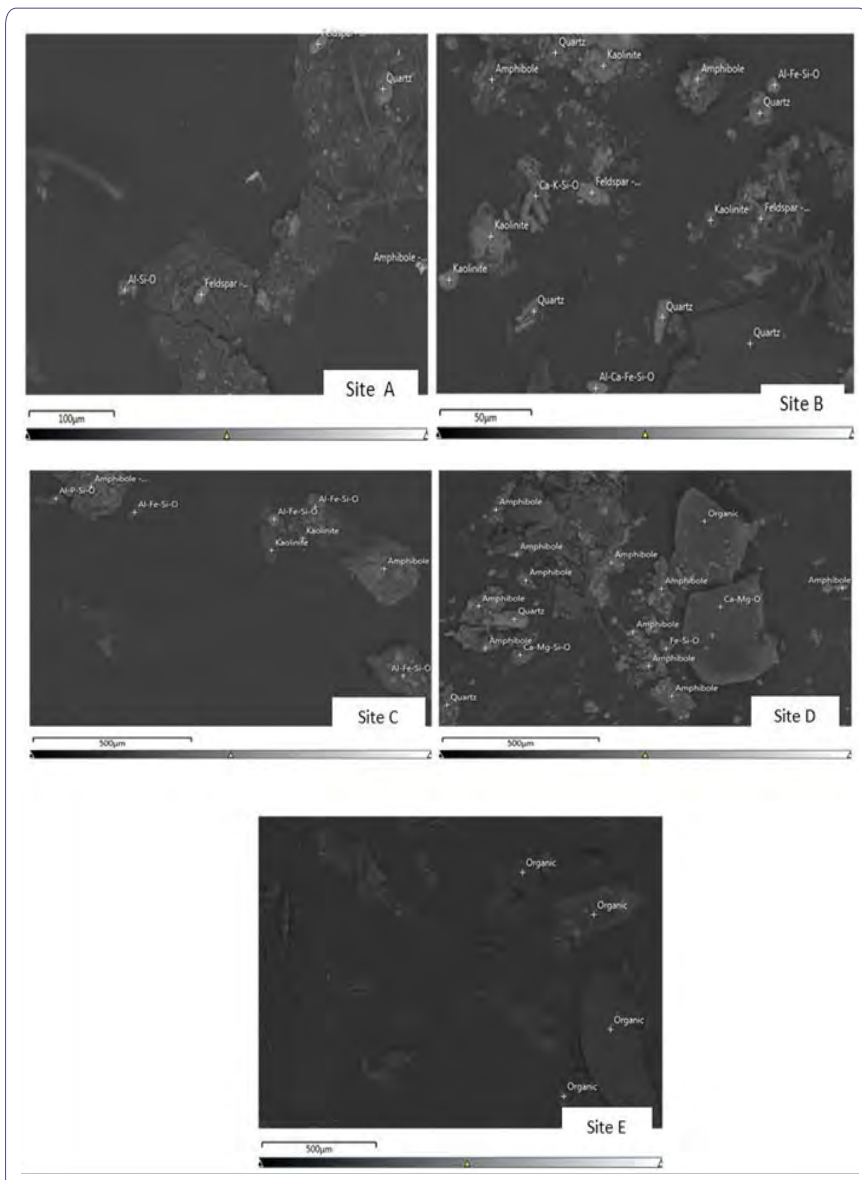

Figure 4: SEM-EDS results.

Site A with $572 \mathrm{f} / \mathrm{mL}$ and Site D2, $189.953 \mathrm{f} / \mathrm{L}$ exceedance the asbestos limit $<100 \mathrm{f} / \mathrm{mL}$ in July 2017. In September 2017 exceedance the rural limit with $1,845.238 \mathrm{f} / \mathrm{mL}$ at Site A \& D. Site D with $572 \mathrm{f} /$ $\mathrm{mL}$ in August 2018 exceeded the rural limit. The storage cassette of the filtered substrates sample were damaged because there were exposed to leaking water before the samples can reach the laboratory for asbestos fibre count analysis. Due to the damage the samples cannot be analysed for physical asbestos fibre count using Phase Contrast Microscope (PCM).

\section{Discussions}

Most of the results from SEM-EDS show that common elements which make up the chemical formulas for the detected asbestos minerals such as $\mathrm{Ca}, \mathrm{Si}, \mathrm{Al}, \mathrm{Mg}, \mathrm{Fe}, \mathrm{K}, \mathrm{C}, \mathrm{O}, \mathrm{P}$ which are the oxides of silicate minerals of asbestos mineral. The dust particles sizes detected from the SEM-EDS instrument ranged from $50 \mu \mathrm{m}-500 \mu \mathrm{m}$ which confirms that the dust particle shape is granular and semi-triangle. The asbestos fibres concentration were detected at Site A and Site D in July 2017, August 2017 at Site D and September 2017 at Sites A \& E and other sites where Sample Damaged (SD) it is due to water leaking which caused contamination of the filter substrates cassette and there was also the low quantity of the filtered substrate dust sample collected on the filter. The data in the table 1 is insufficient but since there is presence of the asbestos mineral this rise a concern that people in the 
Citation: Kwata MG, Moja SJ, Masindi K, Mtyelwa O, Malatji M (2019) Asbestos Fibre and Mineral Counts from Filtered Dust Collected in Human Settlements Asbestos Mine Dumps in Mpumalanga Province, Republic of South Africa. J Environ Sci Curr Res: S1003.

human settlements could be exposed to the mineral. The population size is another factor that should be taken into consideration. These five sites are rehabilitated the concern is that there is an exposure of asbestos minerals from the mine dumps to the human settlements.

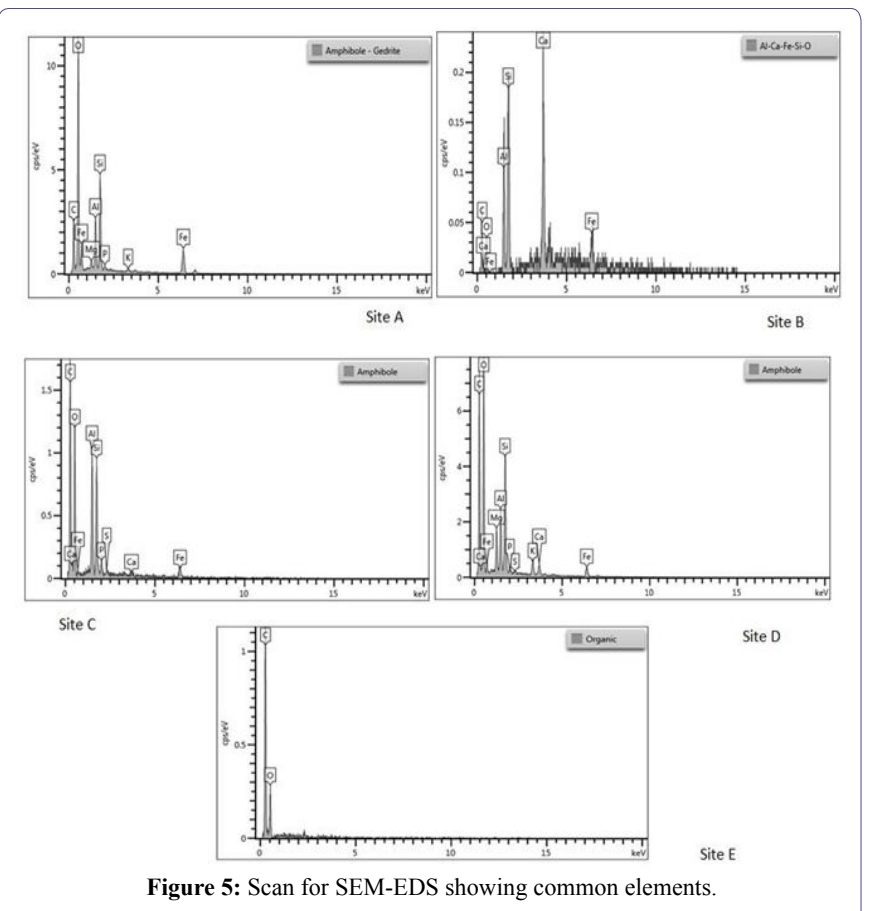

\begin{tabular}{|c|c|c|c|c|c|c|}
\hline & C/No. of Fibres & Site A & Site B & Site C & Site D & Site E \\
\hline \multirow{2}{*}{ 17-Jul } & Conc. (f/mL) & 572 & & & 2.189 & \\
\cline { 2 - 7 } & No. of Fibres & 1 & SD & SD & 4,5 & SD \\
\hline \multirow{2}{*}{ 17-Aug } & Conc. (f/mL) & & & & 572 & \\
\cline { 2 - 7 } & No. of Fibres & SD & SD & SD & 1 & SD \\
\hline \multirow{2}{*}{ 17- Sept } & Conc. (f/mL) & 1.845 & & & & 1.845 \\
\cline { 2 - 7 } & No. of Fibres & 3.5 & SD & SD & SD & 0,5 \\
\hline \multirow{2}{*}{ 17-Oct } & Conc. (f/mL) & & & & & \\
\cline { 2 - 7 } & No. of Fibres & SD & SD & SD & SD & SD \\
\hline \multirow{2}{*}{ 17-Nov } & Conc. (f/mL) & & & & & \\
\cline { 2 - 7 } & No. of Fibres & SD & SD & SD & SD & SD \\
\hline \multirow{2}{*}{ 17-Dec } & Conc. (f/mL) & & & & & \\
\cline { 2 - 7 } & No. of Fibres & SD & SD & SD & SD & SD \\
\hline
\end{tabular}

Table 1: Mpumalanga Province \% asbestos fibre count for AirCon and filter for January to December 2017.

SD: Sample damage.

\section{Conclusion}

This is research was conducted due the asbestos minedumps in close proximity to the human settlement where people are residing. It was important to conduct the study because previous owners of these mines cannot be traced so that they can be liable for the impact on the environment and human health they have caused. The research findings are limited because the research was done only for a year, which it needs at least 3 to 5 years to defend the results. The province specific conditions might have affected the collected samples.
SEM-EDS results detected amphibole asbestos mineral in the province where there were only mining chrysotile asbestos mineral. The exposure of the amphibole asbestos mineral it can be due to movement of trucks from one province to another or accidentally exposed while there were mining chrysotile asbestos mineral. Other silicate minerals detected were quartz, kaolinite and feldspar. Organic material was detected. Asbestos fibre count concentration results shows exceedance at Sites A, Ein July 2017, August 2017 at Site D and in September 2017 at Site A and D. Also the scan graphs confirm that asbestos is geochemical compositions and silicate minerals. These exposed inhalable asbestos fibres to human settlement could cause health problems and deteoriating the environment. The area coverage and population should be taken in consideration as long as there is exposure of asbestos mineral/fibres that it is still a concern. This asbestos mineral exposure it could be through inhalation, ingestion, absorption and injection.

\section{References}

1. Virta R (2005) Mineral commodity profiles- Asbestos U.S. Geological Survey Circular 1255KK, Washington, USA.

2. WHO (2000) Air Quality Guidelines for Europe. World Health Organization, Regional Office for Europe, Copenhagen, Denmark.

3. Maroni M, Seifert B, Landfall T (1995) Air quality monographs: Indoor air quality a comprehensive reference book. Elsevier, New York.

4. WHO (1984) Air Quality Guidelines: Asbestos. WHO Regional Office for Europe, Copenhagen, Denmark.

5. WHO (1986) Asbetsos and other natural minerals fibres. World Health Organization, Geneva, Switzerland.

6. Boulanger G, Andujar P, Pairon JC, Billon-Galland MA, Dion C, et al. (2014) Quantification of short and long asbestos fibers to assess asbestos exposure: A review of fiber size toxicity Environ Health 13:59.

7. Awad AMA (2011) Airborne asbestos fibres and mesothelioma in the last 20 years in Egypt: A review. Atmospheric Pollution Research 2: 445-451.

8. Marfels H (1984) Irnissionsmessungen von faserigen stauben in der Bundeserpublik Deutschland-I. Messuhgen in der Nahe Industriequelle, Measurements of fibrous of an industrial source, Staub, Reinhaltung der Luft .

9. Commins BT (1985) The significance of asbestos and other mineral fibres in environmental ambient air, Commins Ass, Maidenhead, Berkshire.

10. MYE (2015) Statistics South Africa. Mid-year estimates, South Africa.

11. Anahausser CR (1978) The geological evolution of the primitive earth: evidence fromthe Barberton Mountain land. Unversity of the Witswatersrand Johannesburg, Johannesburg, South Africa.

12. Hart HP (1992) Mines move to combat inflation. Engineering news mining supplement.

13. McCulloch J (2008) Surviving blue asbestos: mining and occupational disease in South Africa and Austrailia.

14. Government Gazette (2013) National Dust Control Regulation, Government Gazette, Pg no: 4-8.

15. DWM (2015) American Standard for Testing Material Designated (ATMD) 1739-1970 Standard Method for Collection and Analysis of Dustfall. Dust Watch Manual, South Africa.

16. Brime C (1985) The accuracy of X-ray diffraction method for determining mineral mixtures. Mining Management 49: 531-538.

17. AirCon Manual, AirCon 2 High Volume sampler Code number F- RRO 3100 (2016) Operation and services manual, 2016. 


\section{di}

Journal of Anesthesia \& Clinical Care

Journal of Addiction \& Addictive Disorders

Advances in Microbiology Research

Advances in Industrial Biotechnology

Journal of Agronomy \& Agricultural Science

Journal of AIDS Clinical Research \& STDs

Journal of Alcoholism, Drug Abuse \& Substance Dependence

Journal of Allergy Disorders \& Therapy

Journal of Alternative, Complementary \& Integrative Medicine

Journal of Alzheimer's \& Neurodegenerative Diseases

Journal of Angiology \& Vascular Surgery

Journal of Animal Research \& Veterinary Science

Archives of Zoological Studies

Archives of Urology

Journal of Atmospheric \& Earth-Sciences

Journal of Aquaculture \& Fisheries

Journal of Biotech Research \& Biochemistry

Journal of Brain \& Neuroscience Research

Journal of Cancer Biology \& Treatment

Journal of Cardiology: Study \& Research

Journal of Cell Biology \& Cell Metabolism

Journal of Clinical Dermatology \& Therapy

Journal of Clinical Immunology \& Immunotherapy

Journal of Clinical Studies \& Medical Case Reports

Journal of Community Medicine \& Public Health Care

Current Trends: Medical \& Biological Engineering

Journal of Cytology \& Tissue Biology

Journal of Dentistry: Oral Health \& Cosmesis

Journal of Diabetes \& Metabolic Disorders

Journal of Dairy Research \& Technology

Journal of Emergency Medicine Trauma \& Surgical Care

Journal of Environmental Science: Current Research

Journal of Food Science \& Nutrition

Journal of Forensic, Legal \& Investigative Sciences

Journal of Gastroenterology \& Hepatology Research

Journal of Gerontology \& Geriatric Medicine
Journal of Genetics \& Genomic Sciences

Journal of Hematology, Blood Transfusion \& Disorders

Journal of Human Endocrinology

Journal of Hospice \& Palliative Medical Care

Journal of Internal Medicine \& Primary Healthcare

Journal of Infectious \& Non Infectious Diseases

Journal of Light \& Laser: Current Trends

Journal of Modern Chemical Sciences

Journal of Medicine: Study \& Research

Journal of Nanotechnology: Nanomedicine \& Nanobiotechnology

Journal of Neonatology \& Clinical Pediatrics

Journal of Nephrology \& Renal Therapy

Journal of Non Invasive Vascular Investigation

Journal of Nuclear Medicine, Radiology \& Radiation Therapy

Journal of Obesity \& Weight Loss

Journal of Orthopedic Research \& Physiotherapy

Journal of Otolaryngology, Head \& Neck Surgery

Journal of Protein Research \& Bioinformatics

Journal of Pathology Clinical \& Medical Research

Journal of Pharmacology, Pharmaceutics \& Pharmacovigilance

Journal of Physical Medicine, Rehabilitation \& Disabilities

Journal of Plant Science: Current Research

Journal of Psychiatry, Depression \& Anxiety

Journal of Pulmonary Medicine \& Respiratory Research

Journal of Practical \& Professional Nursing

Journal of Reproductive Medicine, Gynaecology \& Obstetrics

Journal of Stem Cells Research, Development \& Therapy

Journal of Surgery: Current Trends \& Innovations

Journal of Toxicology: Current Research

Journal of Translational Science and Research

Trends in Anatomy \& Physiology

Journal of Vaccines Research \& Vaccination

Journal of Virology \& Antivirals

Archives of Surgery and Surgical Education

Sports Medicine and Injury Care Journal

International Journal of Case Reports and Therapeutic Studies

Journal of Ecology Research and Conservation Biology 